\title{
DISTRIBUTION OF AUSTROPOTAMOBIUS PALLIPES (Lereboullet) IN CROATIA AND NOTES ON ITS MORPHOLOGY
}

\author{
I. MAGUIRE, G. I. V. KLOBUČAR, S. GOTTSTEIN MATOČEC, R. ERBEN
}

Department of Zoology, Faculty of Science, University of Zagreb, Rooseveltov $\operatorname{trg} 6$, 10000 Zagreb, Croatia.

E-Mail: imaguire@public.srce.hr

Reçu le 8 septembre 2003

Received September 8, 2003

Accepté le 9 avril 2004

Accepted April 9, 2004

\begin{abstract}
In order to gain better insight into the distribution of white-clawed crayfish (Austropotamobius pallipes) in Croatia, we pooled together all of the available historical and recent data. The historical data on distribution were compiled from literature and the Croatian Natural History Museum collection. Fieldwork, to evaluate the current distribution of crayfish, took place between 1995 and 2003. The distribution of Austropotamobius pallipes is restricted to the limestone region and therefore the species is found spread in rivers belonging to the Adriatic Sea basin (from NW to SE of Croatia). Those waters are mainly unpolluted and the substrate consists of rocks and stones and crayfish were found near banks. We also occasionally found crayfish in subterranean habitats but as they appear to have no troglomorphic adaptations they are probably of epigean origin. According to data taken from literature, both $A$. pallipes and $A$. torrentium live in the coastal rivers. But to date, we have not yet recorded presence of $A$. torrentium there, while we did record the presence of Astacus astacus. While studying the data from the literature, we were frequently confronted with contradictory findings, therefore, in the near future we are planning to do intensive field research within the coastal region in order to get a clearer picture of the detailed distribution of freshwater crayfish in this part of Croatia.
\end{abstract}

In addition, individuals from four different geographical areas were compared using two morphometric and two meristic characteristics and the results are discussed.

Key-words: Austropotamobius pallipes, Croatia, geographical distribution, morphological characteristics.

\section{DISTRIBUTION D'AUSTROPOTAMOBIUS PALLIPES EN CROATIE ET NOTES SUR SA MORPHOLOGIE}

\section{RÉSUMÉ}

Pour améliorer notre connaissance sur la distribution des écrevisses à pattes blanches (Austropotamobius pallipes) en Croatie, nous avons rassemblé toutes les données historiques disponibles et les résultats de notre recherche. Les données historiques sont issues de la littérature et de la collection du Muséum d'Histoire Naturelle de Croatie. Nous avons étudié la distribution actuelle sur le terrain depuis 1995. La distribution d'A. pallipes est limitée à la région karstique de la Croatie, donc aux fleuves du drainage Adriatique (du Nord-Est au Sud-Ouest de la Croatie). Ces fleuves sont principalement de bonne qualité 
chimique avec des fonds rocheux et caillouteux et les écrevisses peuvent être trouvées à proximité des rives. Pendant notre recherche nous avons enregistré la présence de spécimens d'A. pallipes dans les habitats souterrains. Toutefois, les animaux n'ont pas d'adaptation troglomorphiques et sont en conséquence probablement d'origine épigée. Selon la littérature, dans les fleuves côtiers est présente également $A$. torrentium. Nous n'avons pas trouvé cette espèce mais nous avons trouvé Astacus astacus. Dans la littérature, nous avons fréquemment été confrontés à des contradictions. La recherche sur la distribution des écrevisses dans cette région de la Croatie se poursuivra dans l'avenir et doit être intensifiée. Au cours de notre étude nous avons aussi comparé deux caractères morphométriques et deux caractères méristiques entre des populations.

Mots-clés: Austropotamobius pallipes, Croatie, distribution géographique, morphologie.

\section{INTRODUCTION}

Four native European crayfish species from the family Astacidae can be found in Croatia. These are the noble crayfish (Astacus astacus (Linnaeus)), the Turkish crayfish (Astacus leptodactylus (Eschscholtz)), the white-clawed crayfish (Austropotamobius pallipes (Lereboullet)) and the stone crayfish (Austropotamobius torrentium (Schrank)). Even though stone crayfish, white-clawed and noble crayfish are protected by Croatian Law (Law of Nature Conservation (NARODNE NOVINE, 30/94) and Rule Book on Protection of Crayfish (Crustacea, Astacidae) (NARODNE NOVINE, 76/98)), their biology, ecology and distribution have still not been studied in detail, but it is known that $A$. pallipes is distributed in freshwater habitats that belong to the Adriatic Sea drainage basin (MAGUIRE, 2002).

A. pallipes is found in Southern and Western Europe, including British Isles (LAURENT, 1988; TAYLOR, 2002). It has been frequently studied and it presents a taxon that is highly structured, so the latest suggestion is to consider $A$. pallipes as a complex species (HOLDICH, 2002).

The purpose of this paper is to present the distribution of $A$. pallipes in Croatia and at the same time compare historical data, collected from literature, with recent data collected during our field research.

M. S. KARAMAN $(1961,1962)$ has used morphological and meristic characteristics, to describe different Austropotamobius subspecies in this geographical region. Therefore, in the frame of our study on the distribution of white-clawed crayfish in the rivers belonging to the Adriatic Sea drainage, we compared two morphometrical and two meristic characteristics between $A$. pallipes specimens that we collected from different populations as to relate them to Karaman's descriptions.

\section{MATERIAL AND METHODS}

Historical data on the distribution of Austropotamobius pallipes in Croatia were compiled from literature (GRUBE, 1861; CAR, 1901; ENTZ, 1914; S. KARAMAN, 1929; BOTT, 1950, 1972; M. S. KARAMAN, 1961, 1962, 1963; ALBRECHT, 1982; SKET, 1988; BRUSINA, 1995) and from the astacological collection of the Natural History Museum in Zagreb.

Recent data on the current distribution of $A$. pallipes were collected during our fieldwork, which took place between 1995 and 2003 (GOTTSTEIN and KEROVEC, 1998; GOTTSTEIN et al., 1999; MAGUIRE, 2002).

Animals were caught either by hand, or with LiNi traps (WESTMAN et al., 1978) or with traps made from PVC bottles (cylindrical shape, with funnel entrances at both ends 
made from plastic net, mesh size $=2 \mathrm{~mm}$ ). The traps were baited with fish or pig liver and were left in water overnight.

Identification of the crayfish was done according to BOTT $(1950,1972)$, FROGLIA (1978) and M. S. KARAMAN $(1961,1963)$.

For each finding UTM coordinates were determined and the data were entered into the UTM grid map of Croatia $(10 \times 10 \mathrm{~km})$ (NIKOLIĆ et al., 1998).

For the purpose of morphological comparison between populations we measured (using digital calliper) the length of carapace $(C)$, rostrum (R) and apex (A). In statistical comparison we used index of rostrum and carapace $(R \% C=R / C \times 100)$ and index of apex and rostrum $(A \% R=A / R \times 100)$. We also recorded number of spines on the cervical groove, for left (NSCGL) and right side (NSCGR) of carapace, and number of spines on the merus of the third maxilliped (NS3 ${ }^{r d} \mathrm{Mx}$ ), both for the left and the right maxilliped. The presence of spines on the merus was recorded for its dorsal and ventral side and the position of spines was categorised as proximal (close to the basis, on the first half of the merus), distal (away from the basis, on the second half of the merus) (abbreviations used: NS3 ${ }^{\text {rd }} \mathrm{MxDL}$ and $\mathrm{NS}^{\text {rd }} \mathrm{MxDR}$, for left and right maxilliped, respectively) and ubiquitous (along the whole

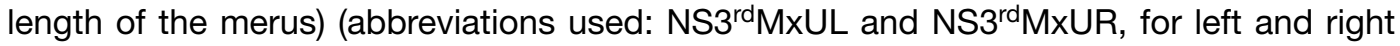
maxilliped, respectively) (Figure 1). For statistical analyses we have chosen four distinct populations, with sufficient numbers of crayfish. Descriptive statistic and Mann-Whitney $U$ Test were performed using Statistica 5.0 and Microsoft Excel programs.

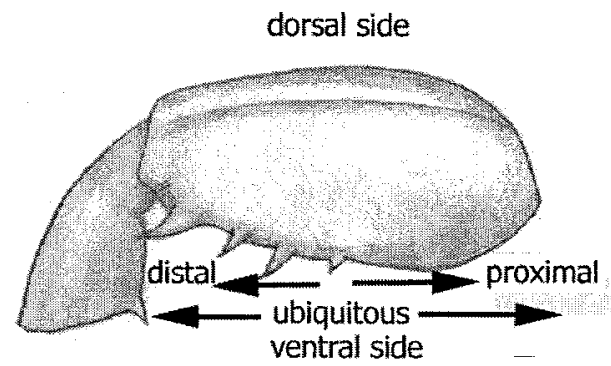

Figure 1

Description of parameters analyzed on the merus of the third maxilliped.

\section{Figure 1}

Description des paramètres analysés sur le mérus du troisième maxillipède.

\section{RESULTS}

The distribution of Austropotamobius pallipes, based on data taken from literature and the Museum collection, is shown in Figure 2. Figure 3 presents data on the distribution of this species that we collected during our field research, while in Figure 4 we superpose historical and recent data on the distribution.

Distribution of $A$. pallipes is restricted to the lakes and rivers belonging to the Adriatic Sea drainage basin (from NW to SE of Croatia) (Figures 2, 3 and 4). That is a limestone region with a complex hydro-geological structure and with freshwaters that are mainly unpolluted and whose substratum consists of rocks, stones and pebbles. Whiteclawed crayfish are normally found along the banks where water current is slower and where aquatic plants are abundant. 


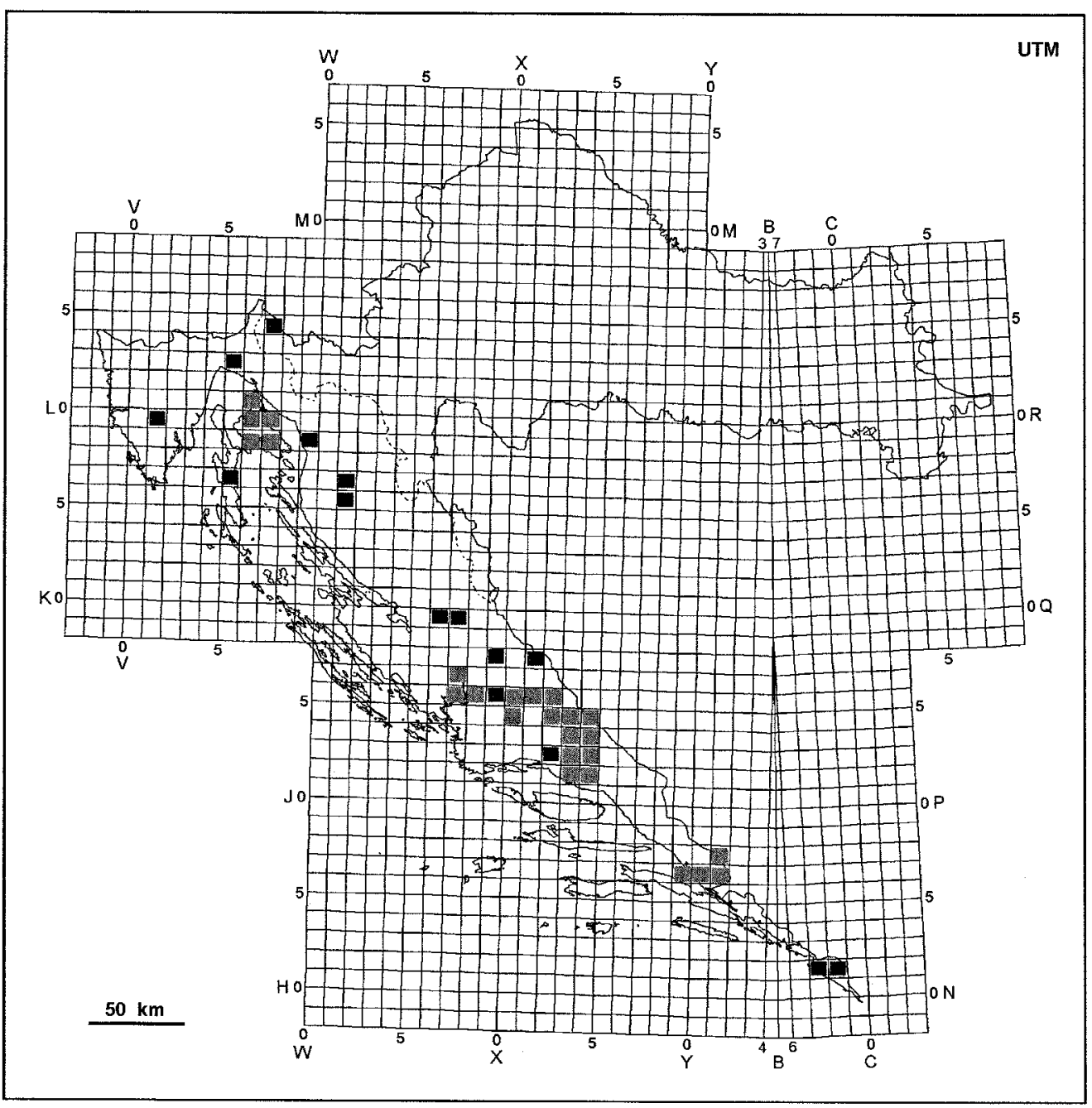

Figure 2

Distribution (by 10-km square) of $A$. pallipes in Croatia based on the data collected from literature and Museum collection (grey colour was used in cases when author did not describe precisely exact locality where crayfish were caught). Dotted line presents the border between the Black Sea drainage and the Adriatic Sea drainage.

Figure 2

Distribution d'A. pallipes (par quadrat de $10 \mathrm{~km} \times 10 \mathrm{~km}$ ) en Croatie selon les données de la littérature et du muséum (la couleur grise a été utilisée quand l'auteur n'a pas décrit précisément la localité exacte où les écrevisses ont été capturées). ........... Ligne de partage des eaux du bassin Adriatique et du bassin de la Mer Noire.

During our research we found $A$. pallipes in two subterranean localities - artificial tunnel Orlovac connected with the Cetina River (XJ 43) in Dalmatia and Spring Bakovac (WK 50) in Lika. They showed no troglomorphic adaptations so it is possible that they entered the underground from epigean habitats through sinking rivers. 


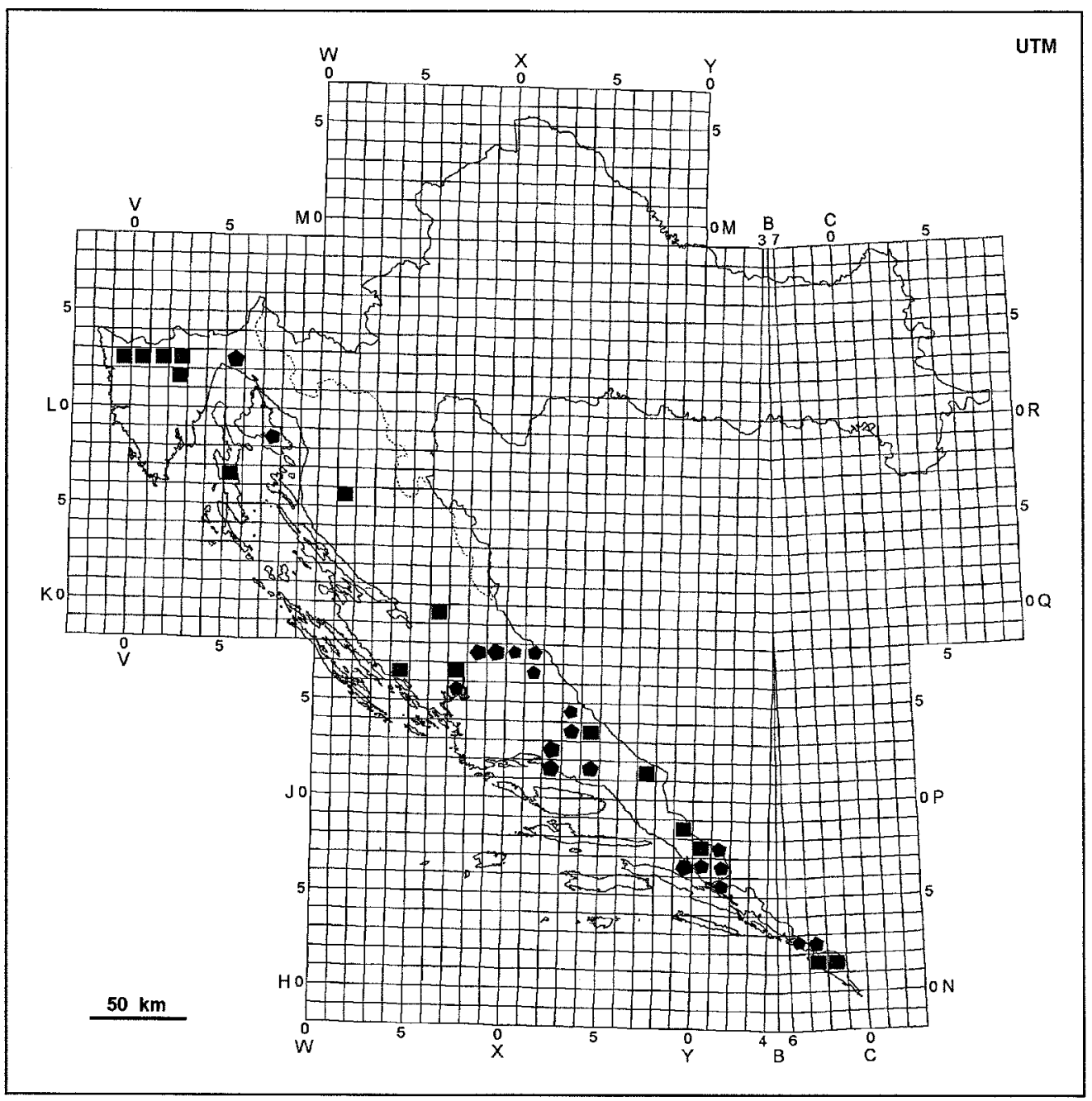

Figure 3

Distribution (by 10-km square) of $A$. pallipes in Croatia based on the results of our research. Black squares present localities where $A$. pallipes was found; black polygons present localities where $A$. pallipes was not found. Dotted line presents the border between the Black Sea drainage and the Adriatic Sea drainage.

Figure 3

Distribution (par quadrat de $10 \mathrm{~km} \times 10 \mathrm{~km}$ ) d'A. pallipes en Croatie selon les résultats de notre recherche. Le carré noir a été utilisé pour la localité où $A$. pallipes a été capturée; le polygone noir a été utilisé pour la localité où $A$. pallipes n'a pas été capturée. ............ Ligne de partage des eaux du bassin Adriatique et du bassin de la Mer Noire.

In coastal rivers, apart from $A$. pallipes, we also found Astacus astacus. This species is naturally widely distributed in the rivers belonging to the Black Sea drainage and its presence in the Adriatic Sea drainage is most probably of anthropogenic origin. The exact time of introduction for the population in Istria (WL 21) is unknown, but for the population in the Velika Paklenica Stream (WK 30) we gathered the information, from local inhabitants, that it had been introduced in the first half of the $20^{\text {th }}$ century. 


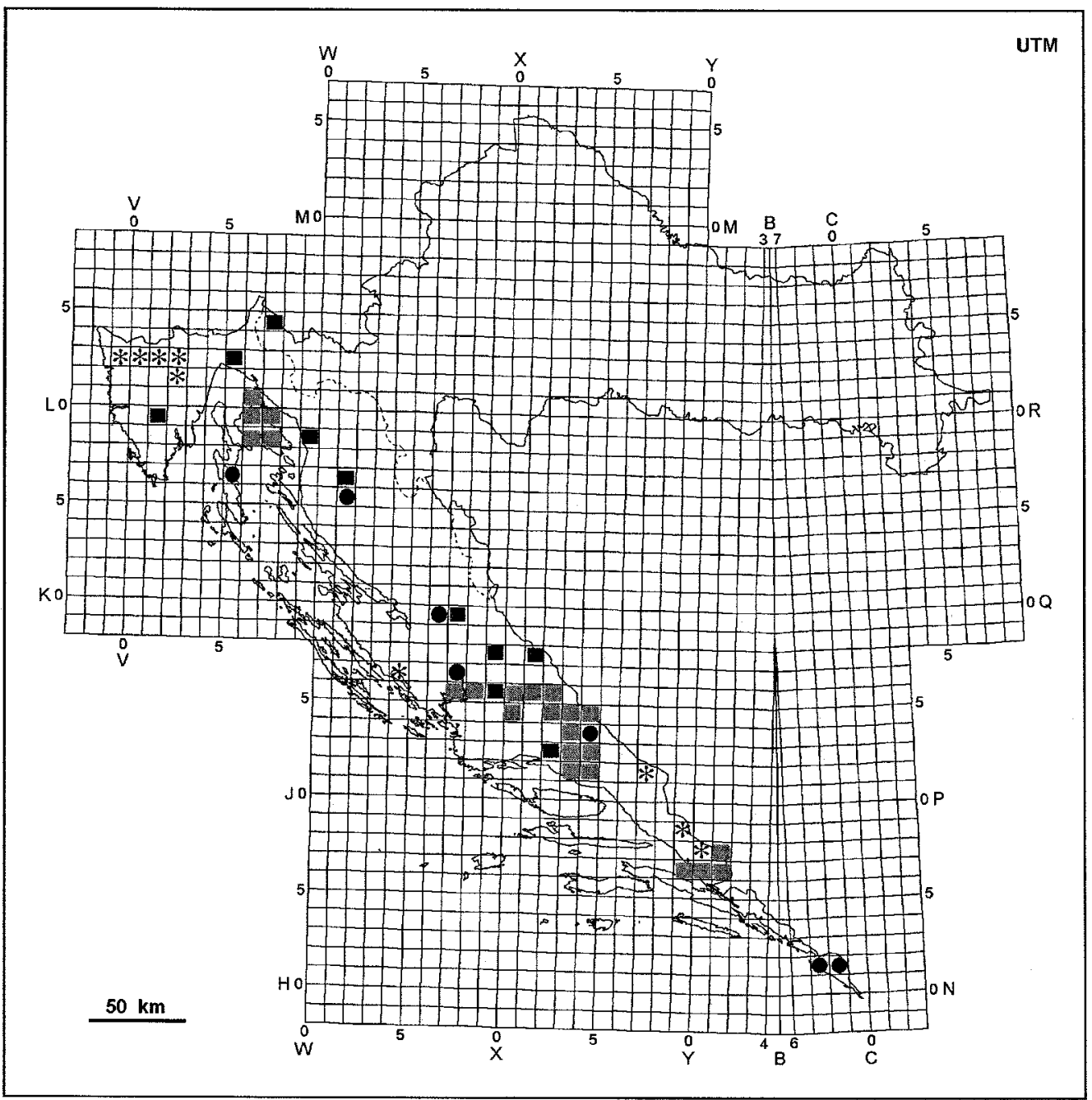

Figure 4

Distribution (by 10-km square) of $A$. pallipes in Croatia based on the results of our field research (black asterisk) and from literature and Museum collection (black squares were used when author described precise locality where crayfish were caught; otherwise, grey squares were used). Black circles present overlap of historical and recent data. Dotted line indicates the border between the Black Sea and Adriatic Sea drainages.

Figure 4

Distribution (par quadrat de $10 \mathrm{~km} \times 10 \mathrm{~km}$ ) de $A$. pallipes en Croatie selon les résultats de notre recherche (astérisque noir) et selon les données rassemblées dans la littérature et au muséum (le carré noir a été utilisé quand l'auteur a décrit précisément la localité où les écrevisses ont été capturées; sinon, le carré gris a été utilisé). Les points noirs représentent la superposition des données historiques et des données récentes. ........... Ligne de partage des eaux du bassin Adriatique et du bassin de la Mer Noire. 
Generally speaking, the distribution range of $A$. pallipes is decreasing due to anthropogenic activities i.e. the lower parts of the watercourses being canalised for agriculture purposes (the Mirna River - VL 12, the Neretva River - YH 07, the Ljuta River BN 71, 81) or middle parts of rivers being used as hydro-accumulations for electric power plants (the Zrmanja River - WJ 69, the Cetina River - XJ 43) or polluted by industry (the Riječina River - VL 52, the Jadro River - XJ 22). Exceptions are protected areas - National Park Krka (the Krka River) - WJ 76 and the Vransko Lake on the island of Cres (source of potable water) - VK 56.

We studied morphological characteristics of 111 white-clawed crayfish from 10 different populations. Statistical comparisons were performed with only four populations, with sufficient number of sampled individuals.

We have not recorded presence of spines on the dorsal side of merus of the third maxilliped in any case, and spines were never present on the proximal part on the ventral side of merus of the third maxilliped, therefore those characters were omitted from further analyses.

The list of localities with UTM coordinates, number of samples per locality and statistical description (minimal, maximal and average values, and standard deviations) of studied characteristics are given in Table I.

We used four populations (Istria, the Vransko Lake-VK 56 on the Island of Cres, Vrljika + Matica Rivers and Modro oko limnocrenic spring - YH 07) to test for statistically significant differences, in recorded morphological characteristics between the populations. Crayfish from the Mirna River (VL 02) and its confluences (the Gradole Source - UL 92, the Račice Stream - VL 22, the Butoniga River - VL 12, the Borutski Stream - VL 21 and an unnamed stream in Antonci - VL 02) were pooled together as Istria, because they are all situated on the Istrian peninsula. Crayfish from the Vrljika River (XJ 71) and the Matica River (XH 98) were pooled together because the population in the Matica River originates from crayfish introduced from the Vrljika River in the year 1988 (information obtained from local inhabitants).

A statistical analysis showed that index of $A \% R$ is significantly different between males and females from Istria and Vransko Lake populations $(p=0.039, p=0.032$, respectively). In addition, male and females from the Vransko Lake were also significantly different in NS3 ${ }^{\text {rd }}$ MxUR $(p=0.045)$. We have not recorded any statistically significant difference between females and males in other populations.

Therefore, in further analyses, we compared males and females separately, between the populations. Results of Mann-Whitney $U$ Test have shown that statistically significant differences, in recorded parameters, between northern (Istria and Vransko Lake) and southern (Vrljika-Matica and Modro oko) populations exist both for males and females (Table II).

When we compared the number of spines on the cervical groove on the left and the right side of the carapace it is evident that, going from the northern to the southern populations, there are more and more specimens per population that have asymmetrically positioned spines (Figure 5).

When we compared position of spines on the merus of the third maxilliped between the studied populations we noticed that the position of spines changes; again going from northern to southern populations spines are positioned more and more distal (Figure 6).

\section{DISCUSSION}

While examining data from the literature and the Museum collection, we frequently encountered terminology problems related to Latin names of species and the existence 


\section{Table I}

\section{Results of descriptive statistics.}

Table I

Résultats statistiques.

\begin{tabular}{|c|c|c|c|c|c|c|c|c|c|c|}
\hline Locality & UTM & value & $\mathrm{R} \% \mathrm{C}$ & $A \% R$ & & NSCGR & NS3 $3^{r d} M X U L$ & NS3 $3^{r d} M x D L$ & NS3rdMxUR & NS3 $3^{r d M x D R}$ \\
\hline \multirow{4}{*}{$\begin{array}{l}\text { Istria } \\
\text { (Mirna } \\
\text { River and } \\
\text { confluences) } \\
(\mathrm{N}=14)\end{array}$} & $\begin{array}{l}\text { UL } 92 \\
\text { VL } 02, \\
12,21 \\
22,\end{array}$ & $\max$ & 30.226 & 41.337 & 4.000 & 4.000 & 5.000 & 4.000 & 6.000 & 3.000 \\
\hline & & $\min$ & 24.809 & 27.262 & 1.000 & 1.000 & 2.000 & 4.000 & 3.000 & 3.000 \\
\hline & & aver & 26.881 & 35.020 & 2.071 & 2.071 & 3.727 & 4.000 & 4.000 & 3.000 \\
\hline & & stdev & 1.558 & 4.254 & 1.072 & 0.917 & 1.009 & 0.000 & 1.000 & 0.000 \\
\hline \multirow{4}{*}{$\begin{array}{l}\text { Vransko Lake } \\
(\text { Cres Island) } \\
(\mathrm{N}=20)\end{array}$} & VK 56 & $\max$ & 28.008 & 37.575 & 6.000 & 6.000 & 7.000 & 2.000 & 6.000 & 2.000 \\
\hline & & $\min$ & 26.241 & 31.274 & 2.000 & 1.000 & 1.000 & 2.000 & 2.000 & 2.000 \\
\hline & & aver & 27.122 & 33.623 & 2.750 & 2.450 & 4.563 & 2.000 & 4.438 & 2.000 \\
\hline & & stdev & 2.081 & 9.302 & 1.069 & 1.099 & 1.413 & 0.000 & 1.064 & 0.000 \\
\hline \multirow{4}{*}{$\begin{array}{l}\text { Krka River } \\
(\mathrm{N}=3)\end{array}$} & WJ 76 & $\max$ & 27.397 & 42.147 & 5.000 & 6.000 & 6.000 & 0.000 & 6.000 & 0.000 \\
\hline & & $\min$ & 25.219 & 29.642 & 3.000 & 2.000 & 3.000 & 0.000 & 3.000 & 0.000 \\
\hline & & aver & 26.567 & 36.563 & 4.000 & 4.333 & 4.000 & 0.000 & 4.000 & 0.000 \\
\hline & & stdev & 1.177 & 6.359 & 1.000 & 2.081 & 1.732 & 0.000 & 1.732 & 0.000 \\
\hline \multirow{4}{*}{$\begin{array}{l}\text { Bakovac } \\
\text { Source } \\
(\mathrm{N}=2)\end{array}$} & WK 15 & $\max$ & 26.245 & 34.707 & 4.000 & 5.000 & 0.000 & 4.000 & 0.000 & 4.000 \\
\hline & & $\min$ & 24.977 & 31.937 & 3.000 & 3.000 & 0.000 & 4.000 & 0.000 & 4.000 \\
\hline & & aver & 25.611 & 33.322 & 3.500 & 4.000 & 0.000 & 4.000 & 0.000 & 4.000 \\
\hline & & stdev & 0.897 & 1.958 & 0.707 & 1.414 & 0.000 & 0.000 & 0.000 & 0.000 \\
\hline \multirow{2}{*}{$\begin{array}{l}\text { Vransko Lake } \\
(\text { Biograd) } \\
(\mathrm{N}=1)\end{array}$} & WJ 46 & & 24.622 & 36.883 & 2.000 & 2.000 & 6.000 & & 6.000 & \\
\hline & & & & & & & & & & \\
\hline \multirow{4}{*}{$\begin{array}{l}\text { Zrmanja River } \\
(\mathrm{N}=2)\end{array}$} & WJ 69 & $\max$ & 27.198 & 37.118 & 5.000 & 6.000 & 3.000 & 0.000 & 4.000 & 0.000 \\
\hline & & $\min$ & 26.156 & 35.805 & 4.000 & 5.000 & 3.000 & 0.000 & 3.000 & 0.000 \\
\hline & & aver & 26.677 & 36.462 & 4.500 & 5.500 & 3.000 & 0.000 & 3.500 & 0.000 \\
\hline & & stdev & 0.737 & 0.928 & 0.707 & 0.707 & 0.000 & 0.000 & 0.707 & 0.000 \\
\hline \multirow{4}{*}{$\begin{array}{l}\text { Vrljika River } \\
(\mathrm{N}=8)\end{array}$} & XJ 71 & $\max$ & 28.871 & 42.857 & 4.000 & 4.000 & 4.000 & 2.000 & 4.000 & 3.000 \\
\hline & & $\min$ & 25.072 & 34.861 & 3.000 & 3.000 & 3.000 & 2.000 & 3.000 & 2.000 \\
\hline & & aver & 26.818 & 38.639 & 3.250 & 3.250 & 3.750 & 2.000 & 3.333 & 2.800 \\
\hline & & stdev & 1.415 & 2.649 & 0.463 & 0.463 & 0.447 & 0.000 & 0.577 & 0.447 \\
\hline \multirow{4}{*}{$\begin{array}{l}\text { Matica River } \\
(N=14)\end{array}$} & $\mathrm{XH} 98$ & $\max$ & 27.117 & 46.179 & 5.000 & 6.000 & 6.000 & 4.000 & 7.000 & 0.000 \\
\hline & & $\min$ & 21.631 & 29.641 & 2.000 & 2.000 & 3.000 & 2.000 & 3.000 & 0.000 \\
\hline & & aver & 24.885 & 37.490 & 3.571 & 3.500 & 4.583 & 3.000 & 4.500 & 0.000 \\
\hline & & stdev & 1.405 & 4.995 & 0.938 & 1.160 & 0.900 & 1.414 & 1.225 & 0.000 \\
\hline \multirow{4}{*}{$\begin{array}{l}\text { Modro Oko } \\
\text { limnocrenic } \\
\text { spring } \\
(\mathrm{N}=47)\end{array}$} & YH 07 & $\max$ & 32.300 & 50.552 & 5.000 & 5.000 & 6.000 & 4.000 & 7.000 & 4.000 \\
\hline & & $\min$ & 21.188 & 29.167 & 2.000 & 2.000 & 4.000 & 2.000 & 3.000 & 2.000 \\
\hline & & aver & 27.887 & 38.830 & 3.255 & 3.149 & 4.500 & 3.212 & 4.375 & 3.129 \\
\hline & & stdev & 2.236 & 5.320 & 0.966 & 0.751 & 0.650 & 0.649 & 0.885 & 0.619 \\
\hline \multirow[t]{4}{*}{$\begin{array}{l}\text { Ljuta River } \\
(\mathrm{N}=2)\end{array}$} & $\begin{array}{l}\text { BN 71, } \\
81\end{array}$ & $\max$ & 29.512 & 41.457 & 3.000 & 3.000 & 0.000 & 4.000 & 0.000 & 3.000 \\
\hline & & $\min$ & 24.302 & 38.796 & 3.000 & 3.000 & 0.000 & 4.000 & 0.000 & 3.000 \\
\hline & & aver & 26.907 & 40.302 & 3.000 & 3.000 & 0.000 & 4.000 & 0.000 & 3.000 \\
\hline & & stdev & 3.684 & 2.130 & 0.000 & 0.000 & 0.000 & 0.000 & 0.000 & 0.000 \\
\hline
\end{tabular}


Table II

Results of Mann-Whitney U test for females and males.

Tableau II

Résultats du test U de Mann-Whitney pour les femelles et les mâles.

\begin{tabular}{|c|c|c|c|c|c|}
\hline \multicolumn{6}{|c|}{ Populations } \\
\hline \multirow{5}{*}{ 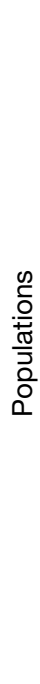 } & Males & Istria & Vransko Lake & Vrljika-Matica & Modro oko \\
\hline & Istria & $x$ & 0 & $\begin{array}{l}\text { A\%R }(p=0.005) \\
\text { NSCGL }(p=0.023) \\
\text { NSCGR }(p=0.045)\end{array}$ & $\begin{array}{l}R \% C(p=0.018) \\
A \% R(p=0.003) \\
\text { NSCGL }(p=0.050)\end{array}$ \\
\hline & $\begin{array}{l}\text { Vransko } \\
\text { Lake }\end{array}$ & $A \% R(p=0.020)$ & $x$ & $\begin{array}{l}\text { R\%C }(p=0.046) \\
\text { NSCGL }(p=0.019) \\
\text { NSCGR }(p=0.006)\end{array}$ & $\begin{array}{l}\text { NSCGR }(p=0.008) \\
N^{N} 3^{r d} M x D L(p=0.028) \\
\text { NS3 }{ }^{\text {rd } M x D R ~}(p=0.030)\end{array}$ \\
\hline & $\begin{array}{l}\text { Vrljika- } \\
\text { Matica }\end{array}$ & $\begin{array}{l}\text { R\%C }(p=0.008) \\
\text { NSCGL }(p=0.019) \\
\text { NSCGR }(p=0.006)\end{array}$ & $\begin{array}{l}R \% C(p=0.029) \\
A \% R(p=0.006)\end{array}$ & $x$ & $\mathrm{R} \% \mathrm{C}(\mathrm{p}=0.003)$ \\
\hline & Modro oko & $\begin{array}{l}\text { NSCGL }(p=0.018) \\
\text { NSCGR }(p=0.009) \\
\text { NS3 } 3^{\text {rd }} \text { MxUL }(p=0.027)\end{array}$ & $A \% R(p=0.004)$ & 0 & $x$ \\
\hline
\end{tabular}

spines on the cervical groove

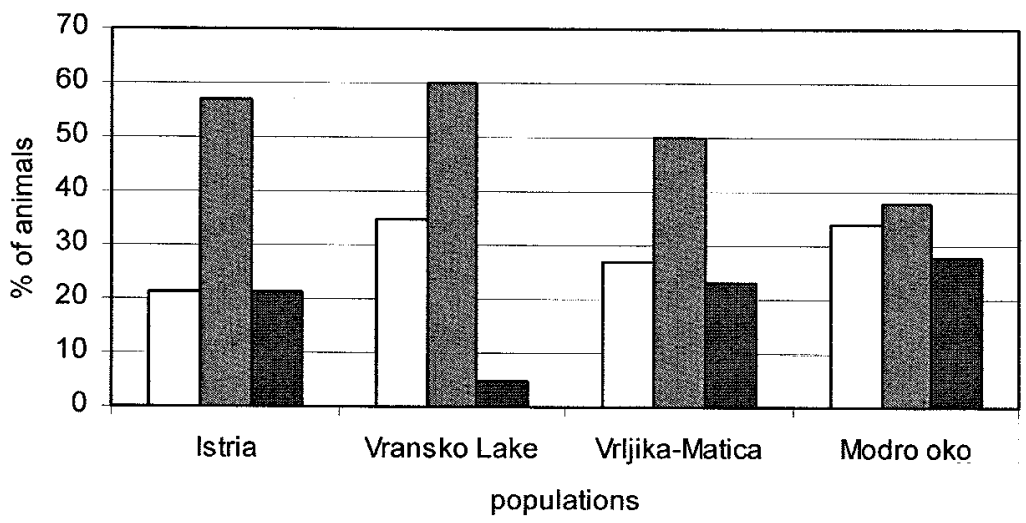

$\square$ more on the left side $\quad$ same on both sides

more on the right side

Figure 5

Percentage of animals, per population, with more spines on the cervical groove of the left side than on the right of the carapace (white column), with the same number of spines on both sides (gray column) and with more spines on the right side than on left (black column).

Figure 5

Pourcentage des animaux, par population, avec plus d'épines en arrière du sillon cervical sur le côté gauche (colonne blanche), avec le même nombre d'épines en arrière du sillon cervical sur les deux côtés (colonne grise) et avec plus d'épines en arrière du sillon cervical sur le côté droit (colonne noire). 
position of spines on the merus of the 3rd maxilliped

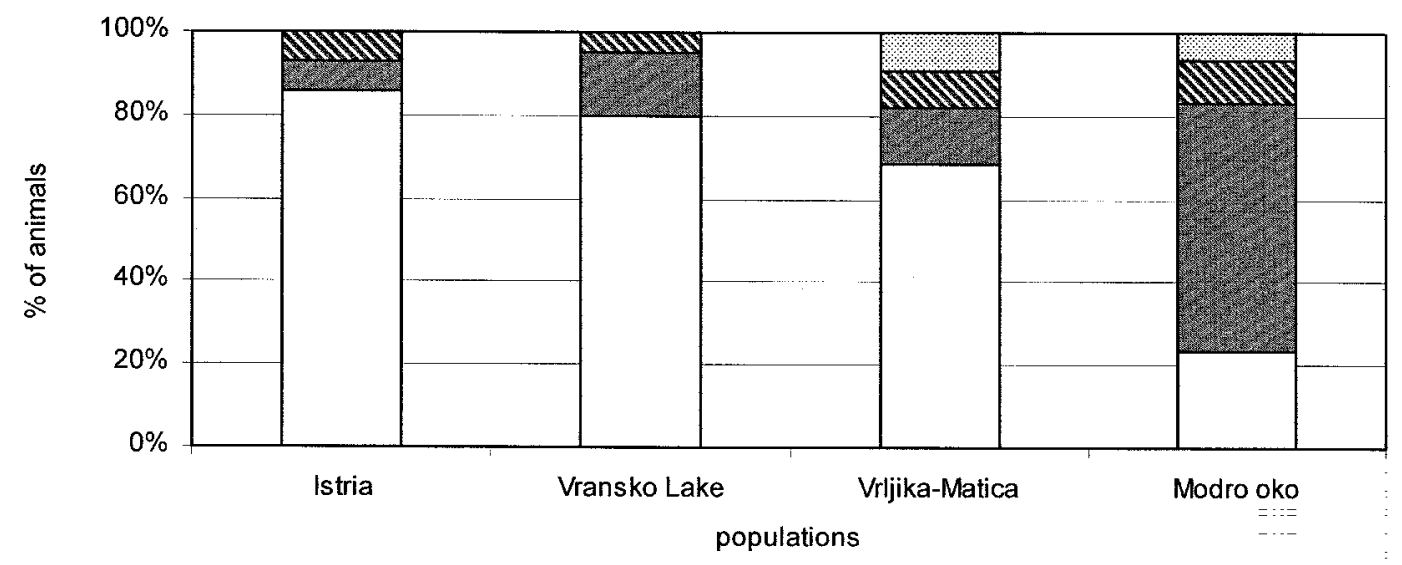

口ubiquitous $L$ ubiquitous $R$ distalL distalR distalL ubiquitous $\mathrm{R}$ ubiquitous $\mathrm{R}$ distalL

\section{Figure 6}

Position of spines on the merus of the third maxilliped, expressed as percentage of animals per population, with spines placed ubiquitous on both maxilliped (white square), with spines placed distal on both maxilliped (gray square), with spines placed distal on the left maxilliped and ubiquitous on the right maxilliped (square with stripes) and with spines placed ubiquitous on the left maxilliped and distal on the right maxilliped (square with dots).

Figure 6

Position des épines sur le mérus du troisième maxillipède, exprimée en pourcentage d'animaux, par population, ayant des épines réparties également sur les deux maxillipèdes (carré blanc), avec des épines en position distale sur les deux maxillipèdes (carré gris), avec des épines réparties sur tout le maxillipède droit et des épines en position distale sur le maxillipède gauche (carré rayé), avec des épines en position distale sur le maxillipède droit et des épines réparties sur l'ensemble du maxillipède gauche (carré avec des points).

of many synonyms for one species. Nineteen synonyms are used for Austropotamobius pallipes (LAURENT, 1988). Also the use of the same synonym for different species was encountered. The name Astacus saxatilis was used for both Austropotamobius torrentium and $A$. pallipes (BOTT, 1950). So, when we came across the finding of Astacus saxatilis in the Vransko Lake on the Island of Cres (GRUBE, 1861), we were not sure which of the two species mentioned was present there. Later M. S. KARAMAN $(1961,1962)$ and SKET (1988) described $A$. pallipes in the Vransko Lake. Our research also confirmed the presence of this species in the Vransko Lake (VK 56) on the Island of Cres (GOTTSTEIN and KEROVEC, 1998). The Lake is a source of drinking water for the islanders and the crayfish were found throughout the whole transect of the lake, down to a depth of $70 \mathrm{~m}$.

Contradictory findings on geographical names of localities from which different authors described $A$. pallipes, and imprecise descriptions of exact localities where the crayfish were caught were also encountered. CAR (1901) found Astacus fluviatilis var. saxatilis in Gornja Švica (WK 17), Kosinj (WK 25) and Jasenica, while M. S. KARAMAN $(1961,1962)$ described $A$. pallipes from Kosinj and Gornja Švica, and $A$. torrentium from Jasenica, the same as ENTZ (1914). All of the localities described here are in fact the names of villages situated in the region of Croatia called Lika and are not the names of 
watercourses. We gave, in the text above, UTM coordinates for all the places except for Jasenica, a name that we have not found on any recent geographical map. So we suppose that either the name has changed and it was different on the old maps, or that the original author (CAR, 1901) made an orthographic mistake that was continued in later scientific papers (ENTZ, 1914; M. S. KARAMAN 1961, 1962). According to our knowledge the closest term to Jasenica is Jesenica, and is found in the name Lička Jesenica, in Lika (WK 38). A similar problem was found in ENTZ's paper (1914) who found A. pallipes in Martijanci. This name is also missing from contemporary maps. The closest name is Martijanka in Istria (VK 19).

During our research in the Krka River (Dalmatia) (WJ 75, 76, 87, 97; XJ 07) we found the presence of $A$. pallipes, the same as ENTZ (1914), S. KARAMAN (1929) and BRUSINA (1995). ALBRECHT (1982) described A. pallipes from the Cikola River (Čikola River) (WJ 85, 95; XJ 04, 05) tributary of the Krka River. He also described $A$. pallipes from Drnis (Drniš) (WJ 95), but according to our knowledge Drniš is a town on the Čikola River and not the name of a watercourse. In the Cetina River (Dalmatia) (XJ 15, 16, 17, 24, 25, 31, 32, 33, 34, $41,42,43,44)$ we collected $A$. pallipes and so did S. KARAMAN (1929), M. S. KARAMAN $(1961,1962)$ and BRUSINA (1995). Apart from $A$. pallipes S. KARAMAN (1929) found $A$. torrentium in the Cetina and Krka Rivers. ALBRECHT (1982) described A. torrentium from the Cetina and Butisnika Rivers (Butižnica, is a tributary of the Krka River)(WJ 99, 98, 97; WK 90; XJ 09, 08). He also found $A$. astacus in the Cetina River, implying that all three species coexist in the Cetina River.

BRUSINA (1995) described A. pallipes from the Rivers Zrmanja (near Bilišane) (WJ 69) and Krupa (WJ 79). M. S. KARAMAN $(1961,1962)$ and BRUSINA (1995) noticed the presence of $A$. pallipes in the Ljuta River (BN 71, 81). During our research we confirmed its presence in these rivers too.

ENTZ (1914) described A. pallipes from Gerovo (VL 74), while we found A. torrentium there, the same as did M. S. KARAMAN (1961, 1962). Since the Gerovica River, that belongs to the Black Sea drainage, runs through Gerovo, we are of the opinion that $A$. pallipes can not have arrived there naturally, and it can be assumed that ENTZ has made a mistake while determining specimens from Gerovo. In rivers that belong to the Black Sea drainage there are no records of $A$. pallipes, but the presence of $A$. torrentium, Astacus astacus and $A$. leptodactylus was recorded (M. S. KARAMAN, 1961, 1962; BRUSINA, 1995; MAGUIRE, 2002).

Another finding of $A$. pallipes, given in literature, is for the Island of Krk from which KARAMAN M. S. (1961, 1962) described Austropotamobius italicus italicus. SKET (1988) and GOTTSTEIN and KEROVEC (1998) did not find the white-clawed crayfish on the Island of Krk, but in communication with the local inhabitants they heard information that the population in Vela Rika (southern part of Krk) was abundant in 1950s.

During our research we found some specimens of $A$. pallipes in a sinkhole near Kosinj (Lika) (WK 15). A. pallipes has been repeatedly collected here since last century (CAR, 1901; ENTZ, 1914; M. S. KARAMAN, 1961, 1962; GOTTSTEIN MATOČEC et al., 2002). It is known (HOBBS III, 2000) that passive transport of crustaceans plays an important role in their dispersion and their frequency in subterranean habitats is in positive correlation with high water velocity during the rainy seasons. This phenomenon is particularly specific in the karstic region of Croatia, where one can find many sinking rivers that bring to underground habitats epigean fauna, including crayfish. As subterranean ecosystems are a food-limited environment, epigean crayfish groups of individuals are there in small numbers and have a low stability (GOTTSTEIN MATOCEEC et al., 2002).

During examination of morphological characteristics of crayfish from ten different populations we noted a certain degree of variability in the size of apex and rostrum, in the 
number of spines on cervical groove and number and the position of spines on the merus of the third maxilliped (Table I, Figures 5 and 6). Using nonparametric statistics we have proven that statistically significant differences, in recorded parameters, between the four studied (chosen) populations exist (Table II).

We have not found any spines on the dorsal side of merus of the third maxilliped and that is in accordance with FROGLIA (1978). The same as BOTT (1950), we have also not found spines on the proximal part of merus of the third maxilliped, but they were present either on the distal part or ubiquitous.

We have also noticed that, apart from statistically significant differences in the number of spines on the cervical groove between the populations, there is an increase, going from the northern to the southern populations, in the number of individuals with unequal number of spines on the left and the right side of the carapace (Figure 5).

According to M.S. KARAMAN (1961), who studied morphology of $A$. pallipes populations in the rivers from the Adriatic Sea basin, the rostrum of crayfish gets wider and the apex smaller going from northern populations to southern ones, and it is possible, based on the shape of rostrum and working with large samples, to distinguish different subspecies. Another morphological characteristic that is useful in determining subspecies, according to M. S. KARAMAN (1961), is the number of spines on the merus of the third maxilliped. He noticed that in northern populations $A$. pallipes have more spines of bigger size, while crayfish in the south have less spines of smaller size on the merus of the third maxilliped. These observations have not been confirmed in our studies but we can say that their position is different. While in northern populations (Istria, Vransko Lake) spines are present on both parts of the merus, in the southern populations (Matica-Vrljika and specially Modro oko) they are present only on the distal part (Figure 6).

These observed differences in morphological characteristics suggest possible genetic differences, which remains to be studied in the future.

While working in the field, we noticed that various anthropogenic activities have destroyed the natural habitats of $A$. pallipes, and have restricted its range of distribution. This is similar to the majority of Europe (BERNARDO et al., 1997; BOHL, 1997; DIÉGUEZURIBEONDO et al., 1997; ALONSO et al., 2000; GRANDJEAN et al., 2000; FÜREDER et al. 2002), where apart from anthropogenic influences a reduction in population size of $A$. pallipes has also been caused by the spread of crayfish plague. Populations of $A$. pallipes in Croatia are isolated in the Adriatic Sea drainage, so that natural spread of this species is almost impossible. Introduction of $A$. astacus to coastal rivers for consumption (although forbidden by law) occurs to some extent so the threat of transmitting disease does exist.

\section{CONCLUSION}

From all that is mentioned, it becomes clear that our knowledge on the distribution in coastal regions, obtained from the literature, still needs to be clarified. Further field research is needed so as to be able to get a complete picture of the distribution of $A$. pallipes in Croatia and to be able to correctly protect this species and its habitats before it is too late. While studying morphological characteristics of white-clawed crayfish we found some significant differences between the northern and southern populations, but in determination of species, as well as using morphological characteristics, we should also use molecular methods (FETZNER and CRANDALL, 2002; HOLDICH, 2002), because the latest genetic studies (GRANDJEAN et al., 2002) indicate that genus Austropotamobius consists of 3 species; torrentium, pallipes and italicus. Austropotamobius italicus includes 3 subspecies; carinthiacus, italicus and carsicus. The latter has been described from Slovenia (GRANDJEAN et al., 2002) so it is possible that some of Croatian populations belong to the same species. 


\section{ACKNOWLEDGEMENTS}

We would like to thank all our colleagues and friends for helping during crayfish collection. We would also like to thank referees for valuable comments that have helped improving this manuscript.

This work was supported by the Scientific Research Council of the Republic of Croatia within the framework of Projects No. 119105 and 119121.

\section{BIBLIOGRAPHY}

ALBRECHT H., 1982. Das system der eurpäischen Flußkrebse (Decapoda, Astacidae): Vorschlag und Begründung. Mitt. hamb. zool. Mus. Inst., 79, 187-210.

ALONSO F., TEMIÑO C., DIÉGUEZ-URIBEONDO J., 2000. Status of the white-clawed crayfish, Austropotamobius pallipes (Lereboullet, 1858), in Spain: distribution and legislation. Bull. Fr. Pêche Piscic., 356, 031-054.

BERNARDO J.M., ILHÉU M., COSTA A.M., 1997. Distribution, population structure and conservation of Austropotamobius pallipes in Portugal. Bull. Fr. Pêche Piscic., 347, 617-624.

BOHL E., 1997. An isolated population of the white-clawed crayfish (Austropotamobius pallipes) in the principality of Liechtenstein. Bull. Fr. Pêche Piscic., 347, 701-712.

BOTT R., 1950. Die Flusskrebse Europas (Decapoda, Astacidae). Abhandlungen der Senckenbergischen Naturforschenden Gesekkschaft, 483, 4-36.

BOTT R., 1972. Besiedlungsgeschichte und Systematik der Astaciden West-Europas unter besonderer Berücksichtigung der Schweiz. Revue Suisse de zoologie, 79 (13), 387-408.

BRUSINA S., 1995. XVI. Prilog za faunu rakâ Dalmacije i Jadranskog mora. In BALABANIĆ J. (ed.), BRUSINA S., Naravoslovne crtice sa sjeveroistočne obale Jadranskog mora, 360-391, Dom i svijet, HAZU, Hrvatski prirodoslovni muzej, Zagreb.

CAR L., 1901. Prilog za faunu Crustaceja. In HEINZ A. (ed.), Glasnik Hrvatskog naravoslovnog društva, 84, 4-6.

DIÉGUEZ-URIBEONDO J., RUEDA a., CASTEIN E., BASCONES J.C., 1997. A plan of restoration in Navarra for the native freshwater crayfish species of Spain, Austropotamobius pallipes. Bull. Fr. Pêche Piscic., 347, 625-637.

ENTZ G., 1914. Über die Flusskebse Ungarns. Matematische und Naturwissenschaftliche Berichte aus Ungarn, 1912 30, 67 - 127 + 4 Tafeln, Leipzig.

FETZNER J.W., CRANDALL K. A., 2002. Genetic variation. In HOLDICH D.M. (ed.), Biology of freshwater crayfish, 291-327, Blackwell science, Oxford.

FROGLIA C., 1978. Decapodi (Crustacea, Decapoda). Guide per il riconoscimento delle specie animali delle acque interne italiane 4. Consiglio Nazionale delle Riserche, Verona, $41 \mathrm{p}$.

FÜREDER L., OBERKOFLER B., HANEL R., MACHINO Y., 2002. Freshwater crayfish in south Tyrol (Italy): Distribution and protection measures of endangered Austropotamobius pallipes. Bull. Fr. Pêche Piscic., 367, 651-662.

GOTTSTEIN S. and KEROVEC M., 1998. Distribution of freshwater and brackish decapods in North-Western Croatia: Preliminary research in Istria, Kvarner and Gorski kotar regions. In ARKO-PIJEVAC M., KOVAČIĆ M., CRNKOVIĆ D. (eds.), Natural history 
researches of the Rijeka region. Natural history library 1, 553-558, Natural History Museum Rijeka, Rijeka [In Croatian with English abstract].

GOTTSTEIN S., KEROVEC M., MAGUIRE I., BUKVIĆ I., 1999. Ecological notes on Austropotamobius pallipes italicus (Faxon, 1914) (Decapoda, Astacidae) in the karstic spring of Neretva delta (Croatia). Freshwater Crayfish, 12, 620-628.

GOTTSTEIN MATOČEC S. (ed.), BAKRAN-PETRICIOLI T., BEDEK J., BUKOVEC D., BUZJAK S., FRANIČEVIĆ M., JALŽIĆ B., KEROVEC M., KLETEČKI E., KRALJ J., KRUŽIĆ P., KUČINIĆ M., KUHTA M., MATOČEC N., OZIMEC R., RAĐA T., ŠTAMOL V., TERNJEJ I., TVRTKOVIĆ N., 2002. An overview of the cave and interstitial biota of Croatia. Natura Croatica, 11 (Suppl. 1), 1-12.

GRANDJEAN F., CORNUAULT B., ARCHAMBAULT S., BRAMARD M., OTREBSKY G., 2000. Life history and population biology of the white-clawed crayfish, Austropotamobius pallipes pallipes, in a brook from the Poitou-Charentes region (France). Bull. Fr. Pêche Piscic., 356, 055-070.

GRANDJEAN F., FRELON-RAIMOND M., SOUTY-GROSSET C., 2002. Compilation of molecular data for phylogeny of the genus Austropotamobius: one species of several? Bull. Fr. Pêche Piscic., 367, 671-680.

GRUBE A.E., 1861. Ein ausflug nach Triest und dem Quarnero. Nicolaische Verlagsbuchhandlung, Berlin, 125.

HOBBS III H.H., 2000. Crustacea. In WILKINS H., CULVER D. and HUMPHREYS W. (eds.), Ecosystems of the World 30, Subterranean Ecosystems, 95-107, Elsevier, Amsterdam.

HOLDICH D.M., 2002. Distrbution of crayfish in Europe and some adjoining countries. Bull. Fr. Pêche Piscic., 367, 611-650.

KARAMAN M.S., 1961. Slatkovodni rakovi Jugoslavije. Publikacije stručnog udruženja za unapredenje slatkovodnog ribarstva Jugoslavije, 3, 1-33.

KARAMAN M.S., 1962. Ein Beitrag zur Systematik Astacidae (Decapoda). Crustaceana, 3, 173-191.

KARAMAN M.S., 1963. Studie der Astacidae (Crustacea, Decapoda) II. Teil. Hydrobiol., 22, 111-132.

KARAMAN S., 1929. Die Potamobiiden Jugoslaviens. Glasnik zemaljskog muzeja u Bosni i Hercegovini, XLI, 147-150.

LAURENT P.J., 1988. Austropotamobius pallipes and A. torrentium, with observations on their interactions with other species in Europe. In HOLDICH D.M. and LOWERY R.S. (eds.), Freshwater crayfish: Biology, Management and Exploitation, 309-340, The University press, Cambridge.

MAGUIRE I., 2002. Family Astacidea in north-west Croatia. PhD thesis (in Croatian with English abstract), University of Zagreb, Croatia, $128 \mathrm{p}$.

NARODNE NOVINE, 30, 1994. Zakon o zaštiti prirode.

NARODNE NOVINE, 76, 1998. Pravilnik o zaštiti riječnih rakova.

NIKOLIĆ T., BUKOVEC D., ŠOPF J., JELASKA S.D., 1998. Kartiranje flore Hrvatske mogućnosti i standardi. Natura Croatica, 7, 1-62.

SKET B., 1988. Zoogeography of the freshwater and brackish Crustacea in the KvarnerVelebit islands (NW Adriatic, Yugoslavia). Biol. vestn., 36, 63-76. 
TAYLOR C. A., 2002. Taxonomy and conservation of native crayfish stocks. In HOLDICH D. M. (ed.), Biology of freshwater crayfish, 236-257, Blackwell science, Oxford.

WESTMAN K., PURSIAINEN M., VILKMAN R., 1978. A new folding trap model which prevents crayfish from escaping. Freshwater crayfish, 4, 235-242. 